\title{
A Comparison of Four Methods Used to Determine the Diets of Large Herbivores
}

\author{
MICHAEL L. MCINNIS, MARTIN VAVRA, AND WILLIAM C. KRUEGER
}

\section{Abstract}

Esophageal fistulation, stomach content analysis, fecal analysis, and forage utilizarion were compared as techniques for determining food habits of large herbivores. Each technique was evaluated based upon information collected using bi-fistulated (esophageal and rumen) sheep during 2 study phases. In the first study phase, microscope slide mounts were made of plant fragments collected from the esophagus, rumen, and feces of 10 confined sheep fed a hand-composited mixture of forage. Dietary composition as determined by each technique was compared to the original feed. Stomach content analysis and fecal analysis produced dietary estimates higher in grasses and lower in forbs than the known feed values. Esophageal fistulation results were not significantly different from the known feed values. In the second study phase, esophageal, rumen, and fecal collections were gathered from 16 sheep grazing a common plant community. Ocular estimates of forage utilization were made concurrently. All data were converted to percent composition on a dry weight basis for comparisons. Significant differences in percent diet composition among techniques occurred for 18 of the 31 plant species consumed. Diets determined by stomach content analysis and fecal analysis were significantly higher in grasses and lower in forbs than those determined by esophageal fistulation and ocular estimates of utilization.

Dietary information of large free-roaming herbivores has become an increasingly important tool in resource management. Such information allows assessment of nut rient intake of animals and evaluation of potential forage competition among herbivorous species. Microscopic examination of plant residues recovered from esophageal fistulae, stomach contents, and feces are 3 common methods of determining food habits of large herbivores. A fourth approach to estimating consumption is by observing or measuring utilization of forage plants. Associated with each of these methods are a number of advantages and disadvantages which have stimulated discussion as to which is most useful in interpreting food habits of large herbivores.

The use of esophageal fistulation has been successful in defining the diets of domestic animals (Vavra et al. 1978) but has not been used appreciably with wild ruminants (Rice 1970). Problems associated with esophageal fistulation are: (1) surgery (Rice 1970); (2) incomplete collections (Lesperance et al. 1974); (3) grazing behavior of fistulated animals may differ from that of intact animals (Engels and Malan 1973).

Examination of rumen ingesta has been a widely used technique to ascertain diets of domestic and wild herbivores. The essential limitations of the technique are: (1) rumen fistulation or sacrifice of the animal is required; (2) stomach analysis may be biased toward less digestible materials in the diet (Rice 1970).

Microhistological examination of fecal material has become a popular technique in recent years. It does not interfere with the

\footnotetext{
Authors are graduate research assistant and professors, Department of Rangeland Resources, Oregon State University, Corvallis, respectively. Vavra is located at Eastern Oregon Agricultural Research Center, Union, Ore.

This article was submitted as Technical Paper No. 6292. Oregon Agricultural Experiment Station, Corvallis.

Manuscript received March 22, 1982.
}

normal grazing habits of the animal (Crocker 1959); is advantageous when 2 or more herbivorous species are utilizing the same range (Korfhage 1974); and is the only feasible procedure to use when studying secretive or endangered species where observations or rumen collections cannot be conducted (Anthony and Smith 1974).

Utilization estimates have been made by several workers to determine the diets of large herbivores (Laycock et al. 1972, Smith and Shandruk 1979, Johnson and Pearson 1981). Such estimates, especially when ocular, are subject to observer error and personal biases (Smith and Shandruk 1979). Furthermore, estimates are confounded by "invisible utilization"such as occurs when a plant is pulled up by the grazing animal; "extraneous utilization" due to trampling or weathering; use too light to be detected; or the presence of more than one species of herbivore (Martin 1970).

Partial comparisons of these 4 techniques have been made. Laycock et al. (1972) determined that esophageal fistulation and ocular utilization estimates gave similar figures for dietary composition of sheep (Ovis aires). Anthony and Smith (1974) found that fecal analysis resulted in higher estimates of grasses, trees, and shrubs, and lower estimates of forbs as compared to rumen analysis. Vavra et al. (1978) identified a higher grass component and lower forb component in fecal samples as compared to esophageal fistula extrusa of steers (Bos taurus). However, these authors found similar importance value rankings of individual plant species in diets as determined by the 2 techniques. Smith and Shandruk (1979) identified fewer species in the feces of pronghorn (Antelocapra americana) than in rumen samples; and even fewer species were recorded by utilization estimates. Johnson and Pearson (1981) found forbs in esophageal samples that were not detected in fecal samples.

The objective of this study was to compare esophageal fistulation, stomach content analysis, fecal analysis, and ocular utilization estimates as techniques to determine the diets of domestic sheep.

\section{Methods}

The study was conducted in 2 phases: (1) in a feeding trial, bi-fistulated (esophageal and rumen) sheep were individually confined and fed a diet of known composition to compare esophageal fistulation, stomach content analysis, and fecal analysis; (2) in a grazing trial, bi-fistulated sheep were allowed to select their own diets from a native meadow to compare forage utilization estimates, esophageal fistulation, stomach content analysis, and fecal analysis.

Esophageal fistulae were installed in all sheep according to the technique of Harris et al. (1967). Closure of these fistulae was accomplished by a removable stainless steel plate onto which was attached a removable rubber stopper. Rumen fistulae were installed in all sheep according to the procedures of McCann et al. (1973).

\section{Feeding Trial}

In early July a field of ladino clover (Trifolium repens) and fawn fescue (Festuca arundinaceae) and a separate field of alfalfa (Medi- 
cago sativa) and orchardgrass (Dactylis glomerata) were mowed. One hundred thirty-six kilograms of each of these 2 mixtures were ground together in a Gehl 120 mobile grinder to reduce particle size and insure mixing, thereby eliminating the possibility of animals selecting particular species. This forage was combined with enough molasses to reduce dust and enhance palatability and fed to 10 bi-fistulated sheep maintained in separate barn stalls.

After a 5-day adjustment period of this forage, a feeding trial lasting 7 consecutive days was conducted as follows: (1) in the morning of each day, every animal was outfitted with an esophageal collection bag and fed the mixture ad libitum; (2) after about one-half hour of feeding, the bags were removed, and their contents collected; (3) rumen ingesta was collected with a pair of tongs inserted through the cannula; (4) fecal material was recovered from the rectum of each animal; (5) a grab sample of forage was collected from each stall; (6) all forage was removed from the stalls each evening to prevent feeding at night and help insure feeding the next morning. Three microscope slides were prepared for each sample following the procedures of Sparks and Malechek (1968). Each slide was examined at the rate of 20 fields (systematically selected) at 100 power magnification. Frequency of occurrence of each species was converted to percent composition by dry weight (Sparks and Malechek 1968). These data were averaged over days to yield a single mean per sheep for each sampling method. Means were compared using Duncan's new multiple-range test (Steel and Torrie 1960) at the $95 \%$ confidence level.

\section{Grazing Trial}

This study phase was conducted on the Hall Ranch of the Eastern Oregon Agricultural Research Center in northeastern Oregon. The 1.6-ha study area was located on a "dry meadow" approximating the description of Hall (1973). The vegetation was nearly uniform throughout the area and was dominated by Northwest cinquefoil (Potentilla gracilis) and velvet lupine (Lupinus leucophyllus). A grazing trial was conducted in July to compare results of the various methods.

Prior to the trial, 10 randomly selected $0.446 \mathrm{~m}^{2}$ circular plots were established in each of 80.1 -ha experimental pastures and individually protected with wire cages. The green weight of each protected species was estimated (Pechanec and Pickford 1937a). Immediately following the grazing trial all sheep were removed from the study area. Ten $0.446 \mathrm{~m}^{2}$ circular plots were located in each pasture and used to estimate percent utilization of current annual growth by species (Pechanec and Pickford 1937b).

Sheep were collectively maintained on a 0.8 -ha holding pasture for 5 days prior to the initiation of the grazing trial to allow the animals to become adjusted to the vegetation. At the end of this period, 2 sheep were randomly assigned to each of the experimental pastures where they remained for the duration of the trial.

Prior to dawn of each of the 7 consecutive mornings of the trial, the sheep were outfitted with esophageal collection bags and allowed to graze for approximately one-half hour. At the end of this period, esophageal extrusa was collected, and a pair of tongs was used to collect rumen ingesta. Every evening of the trial, several pellets from as many fresh fecal groups as could be found within each pasture were gathered and composited by pasture and day. Three microscope slides were prepared for each sample as previously described.

The estimated percentage of utilization of each species obtained through the utilization technique was multiplied by its average dry weight production to estimate the amount eaten (Laycock et al. 1972). The percent dry weight composition of each species was then calculated to enable comparisons with the other techniques. Data from each sampling method were pooled separately for each pasture and averaged over days to yield a single mean for each method and pasture. Means were compared using Duncan's new multiplerange test (Steel and Torrie 1960) at the 95\% confidence level. The similarity between botanical composition of the diets as determined by each method was studied using Kulczynski's similarity index (Oosting 1956).

\section{Results}

\section{Feeding Trial}

No significant difference occurred between the proportion of grass in the control (hand-composited feed) and in esophageal extrusa samples (Fig. 1). Rumen samples contained significantly less grass than fecal samples, but more grass than either control or esophageal samples. The amount of grass in fecal samples was significantly higher than found with the other sampling locations (Fig. 1). Rumen samples contained a significantly lower forb content than did the control or samples of esophageal extrusa. Fecal samples contained a significantly lower percentage of forbs than samples from other sampling methods.

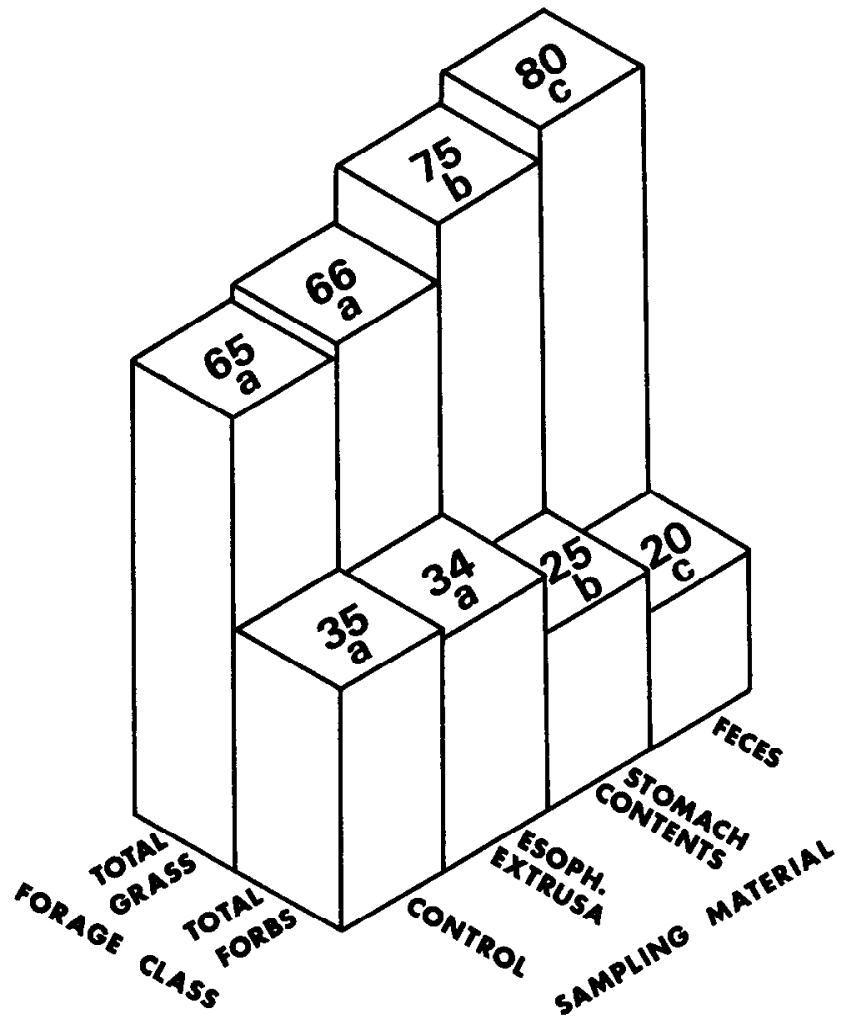

Fig. 1. Percent composition of total grasses and forbs in diets as determined by three methods during the feeding trial. Methods sharing a common letter within forage classes are not significantly different $(\mathrm{p}<0.05)$.

There was no significant difference between the proportion of fawn fescue in esophageal samples and in the control (Fig. 2). No significant difference between the amount of this grass in rumen and fecal samples occurred, but both of these sampling locations contained significantly more fawn fescue than the control or esophageal samples. The amount of orchardgrass in fecal samples was significantly higher than as determined by other sampling methods (Fig. 2). No significant difference among the amounts of this grass in the control, esophageal samples, and rumen samples was noted.

Fecal analysis demonstrated significantly lower amounts of alfalfa than as determined by other methods (Fig. 2). The amount of alfalfa in rumen ingesta was not significantly different than that contained in esophageal samples, but was significantly lower than in the control. The amount in the control did not differ significantly from that found in esophageal extrusa. Ladino clover in the control was significantly higher than in rumen and fecal samples, but was not significantly different than the amount contained in esophageal samples (Figure 2). Similarity between the botanical composition of the total diet (averaged over species) for the control, and each sampling method suggested that the esophageal fistula technique described botanical composition of the control more accurately than other methods (Table 1). The composition of 


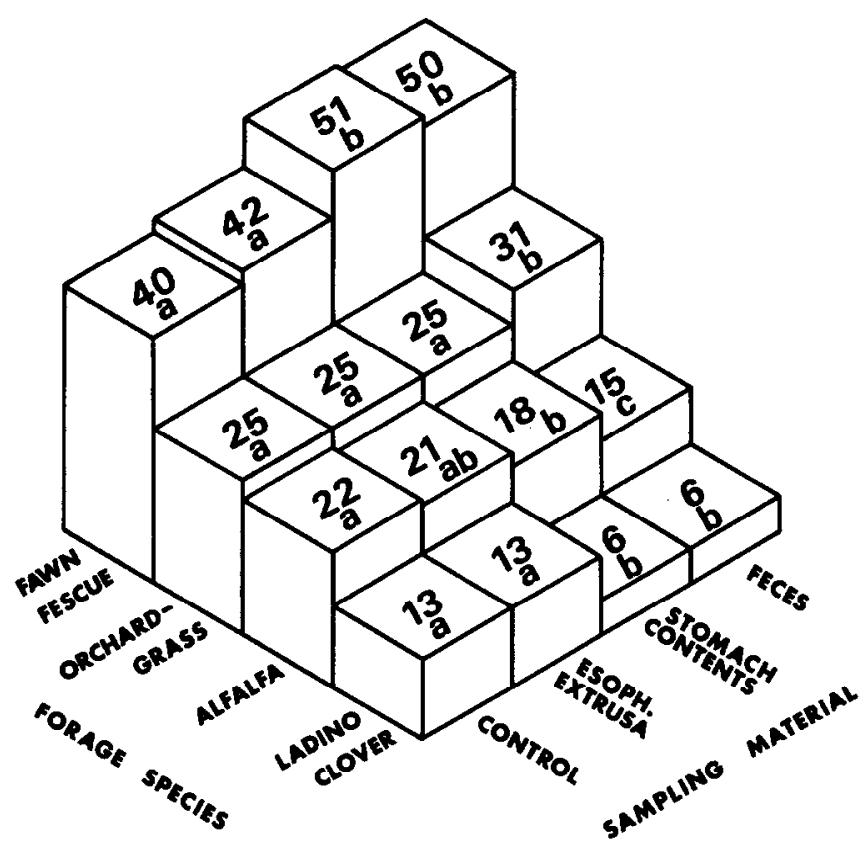

Fig. 2. Percent composition of individual forage species in diets as determined by three methods during the feeding trial. Methods sharing a common letter within species are not significantly different $(\boldsymbol{\alpha}<0.05)$.
Table 1. Similarity of methods used to determine diets of large herbivores.

\begin{tabular}{lc}
\hline \hline Comparison & $\%$ similarity \\
\hline Feeding Trial & \\
Hand-composited feed vs. Esophageal fistulation & 98 \\
Hand-composited feed vs. Rumen analysis & 89 \\
Hand-composited feed vs. Fecal analysis & 80 \\
Esophageal fistulation vs. Rumen analysis & 90 \\
Esophageal fistulation vs. Fecal analysis & 82 \\
Rumen analysis vs. Fecal analysis & 88 \\
Grazing Trial & \\
Utilization estimate vs. Esophageal fistulation & 85 \\
Utilization estimate vs. Rumen analysis & 69 \\
Utilization estimate vs. Fecal analysis & 62 \\
Esophageal fistulation vs. Rumen analysis & 83 \\
Esophageal fistulation vs. Fecal analysis & 76 \\
Rumen analysis vs. Fecal analysis & 93 \\
\hline
\end{tabular}

rumen ingesta was more similar to that of the control than was fecal material.

\section{Grazing Trial}

Of the 13 graminoids occurring on the study area, 11 were identified in diet samples (Table 2). All of these were found in esophageal and rumen ingesta. Utilization estimates failed to show the presence of 4 species of graminoids. Only one species of grass was not found in fecal samples. There were significant differences among the mean values of the sampling procedures for 8 of the graminoids (Table 2).

Table 2. Percent dry weight composition of forage species identified in the diets of sheep as determined by four methods.

\begin{tabular}{|c|c|c|c|c|}
\hline \multirow[b]{2}{*}{ Species } & \multicolumn{4}{|c|}{ Percent composition } \\
\hline & Utilization & Esophageal & Rumen & Fecal \\
\hline $\begin{array}{l}\text { Graminoids } \\
\text { Kentucky, bluegrass (Poa pratensis) } \\
\text { Timothy (Phleum pratense) } \\
\text { Prairie junegrass (Koeleria cristata) } \\
\text { Smooth brome (Bromus inermis) } \\
\text { California danthonia (Danthonia californica) } \\
\text { Western needlegrass (Stipa occidentalis) } \\
\text { Soft chess (Bromus mollis) } \\
\text { Idaho fescue (Festuca idahoensis) } \\
\text { Baltic rush (Juncus balticus) } \\
\text { Sedges (Carex spp.) } \\
\text { Canada bluegrass (Poa compressa) } \\
\text { Total graminoids }\end{array}$ & $\begin{array}{c}8.6^{\mathrm{a}} 1 \\
15.3^{\mathrm{a}} \\
0.5^{\mathrm{a}} \\
0^{\mathrm{a}} \\
0.2^{\mathrm{a}} \\
0^{\mathrm{a}} \\
0^{\mathrm{a}} \\
0^{\mathrm{a}} \\
1.8^{\mathrm{a}} \\
8.9^{\mathrm{a}} \\
0.2^{\mathrm{a}} \\
35.5^{\mathrm{a}}\end{array}$ & $\begin{array}{r}23.7^{b} \\
8.9^{b} \\
3.5^{b} \\
1.6^{b} \\
1.2^{b} \\
1.0^{b} \\
0.7^{b} \\
0.1^{b} \\
0.9^{a} \\
8.8^{a} \\
0.2^{a} \\
50.6^{b}\end{array}$ & $\begin{array}{c}34.7^{\mathrm{c}} \\
13.5^{\mathrm{a}} \\
1.8^{\mathrm{c}} \\
1 . \mathrm{1}^{\mathrm{a}} \\
1.2^{\mathrm{b}} \\
1.5^{\mathrm{b}} \\
1.6^{\mathrm{c}} \\
0.1^{\mathrm{b}} \\
1.5^{\mathrm{a}} \\
9.9^{\mathrm{a}} \\
0.3^{\mathrm{a}} \\
67.2^{\mathrm{c}}\end{array}$ & $\begin{array}{c}36.4^{\mathrm{c}} \\
15.8^{\mathrm{a}} \\
2.2^{\mathrm{c}} \\
1.8^{\mathrm{b}} \\
1.6^{\mathrm{b}} \\
1.7^{\mathrm{c}} \\
1.7^{\mathrm{c}} \\
\mathrm{T}^{\mathrm{a}} \mathrm{c}^{\mathrm{a}} .8^{\mathrm{a}} \\
9.6^{\mathrm{a}} \\
0^{\mathrm{a}} \\
72.6^{\mathrm{c}}\end{array}$ \\
\hline $\begin{array}{l}\text { Forbs } \\
\text { Field horsetail (Equiserum arvense) } \\
\text { Northwest cinquefoil (Potentilla gracilis) } \\
\text { Oregon checkermallow (Sidalcea oregana) } \\
\text { Yellow salsify (Tragopogcn dubius) } \\
\text { Common dandelion (Taraxacum officinale) } \\
\text { Sticky geranium (Geranium viscosissimum) } \\
\text { Missouri goldenrod (Solidago missouriensis) } \\
\text { Orange arnica (Arnica fulgens) } \\
\text { Pale agoseris (Agoseris glauca) } \\
\text { Gland cinquefoil (Potentilla glandulosa) } \\
\text { Rose pussytoes (Antennaria rosea) } \\
\text { Hook violet (Viola adunca) } \\
\text { Yarrow (Achillea millefolium) } \\
\text { Strawberry (Fragaria virginiana) } \\
\text { American vetch (Vicia americana) } \\
\text { Rockymountain iris (Iris missouriensis) } \\
\text { Low fleabane (Erigeron pumilus) } \\
\text { Autumn willowweed (Epilobium paniculatum) } \\
\text { Sheep sorrel (Rumex acetosella) } \\
\text { Prairiesmoke avens (Geum triftorum) } \\
\text { Total forbs }\end{array}$ & $\begin{array}{c}5.4^{\mathrm{a}} \\
30.5^{\mathrm{a}} \\
10.0^{\mathrm{a}} \\
2.7^{\mathrm{a}} \\
1.0^{\mathrm{a}} \\
0^{\mathrm{a}} \\
1.4^{\mathrm{a}} \\
1.0^{\mathrm{a}} \\
3.7^{\mathrm{a}} \\
\mathrm{T}^{\mathrm{a}} \\
\mathrm{T}^{\mathrm{a}} \\
\mathrm{T}^{\mathrm{a}} \\
1.3^{\mathrm{a}} \\
\mathrm{T}^{\mathrm{a}} \\
6.5^{\mathrm{a}} \\
0.6^{\mathrm{a}} \\
0^{\mathrm{a}} \\
0.1^{\mathrm{a}} \\
0.2^{\mathrm{a}} \\
\mathrm{T}^{\mathrm{a}} \\
64.4^{\mathrm{a}}\end{array}$ & $\begin{array}{l}13.0^{\mathrm{b}} \\
20.5^{\mathrm{a}} \\
5.5^{\mathrm{b}} \\
7.9^{\mathrm{b}} \\
1.3^{\mathrm{a}} \\
\mathrm{T}^{\mathrm{b}} \\
\mathrm{T}^{\mathrm{b}} \\
\mathrm{T}^{\mathrm{b}} \\
\mathrm{T}^{\mathrm{b}} \\
\mathrm{T}^{\mathrm{a}} \\
\mathrm{T}^{\mathrm{a}} \\
\mathrm{T}^{\mathrm{a}} \\
0.1^{\mathrm{a}} \\
\mathrm{T}^{\mathrm{a}} \\
0.2^{\mathrm{a}} \\
0 . .^{\mathrm{a}} \\
\mathrm{T}^{\mathrm{a}} \\
\mathrm{T}^{\mathrm{a}} \\
\mathrm{T}^{\mathrm{a}} \\
\mathrm{T}^{\mathrm{a}} \\
48.6^{\mathrm{b}}\end{array}$ & $\begin{array}{l}13.8^{b} \\
8.0^{b} \\
2.0^{b} \\
8.6^{b} \\
T^{b} \\
0^{a} \\
0^{b} \\
T^{b} \\
0^{b} \\
T^{a} \\
T^{\mathbf{b}} \\
T^{a} \\
0.1^{a} \\
T^{a} \\
T^{a} \\
T^{a} \\
T^{a} \\
T^{a} \\
0.1^{a} \\
T^{a} \\
32.6^{c}\end{array}$ & $\begin{array}{c}12.9^{\mathrm{b}} \\
5.9^{\mathrm{b}} \\
1.2^{\mathrm{b}} \\
6.8^{\mathrm{b}} \\
0^{\mathrm{b}} \\
0^{\mathrm{a}} \\
0^{\mathrm{b}} \\
0^{\mathrm{b}} \\
0^{\mathrm{b}} \\
0^{\mathrm{a}} \\
0^{\mathrm{a}} \\
0^{\mathrm{a}} \\
0^{\mathrm{a}} \\
0^{\mathrm{a}} \\
0^{\mathrm{a}} \\
0^{\mathrm{a}} \\
0^{\mathrm{a}} \\
0^{\mathrm{a}} \\
0^{\mathrm{a}} \\
0^{\mathrm{a}} \\
26.8^{\mathrm{c}}\end{array}$ \\
\hline
\end{tabular}

'Dietary composition with the same letters within plant species are not significantly different at the 95 percent confidence level.

${ }_{2} \mathrm{~T}=$ trace; less than $0.1 \%$. 
Ot the 34 species of forbs occurring on the study area, 20 were identified in diet samples (Table 2). All of these were found in esophageal extrusa. Seventeen species of forbs were found in rumen ingesta, four species of forbs were identified in fecal samples, and 18 species of forbs were determined to be dietary components by utilization estimates. Significant differences occurred among the mean values of the sampling methods of 9 of the forb species occurring in the diet (Table 2). Table 1 demonstrates the similarity between total dietary composition (averaged over species) as determined by each method.

\section{Discussion}

Results of the feeding and grazing trials were similar. In the feeding (Figure 1) and the grazing trials (Figure 3) there was a consistent disappearance of forbs as they passed through the digestive tract as indicated by lower percentages contained in the feces than in the rumen, and lower percentages contained in the rumen than in the esophagus. This relationship was consistent with the findings of Regal (1960) and Vavra et al. (1978). Cell wall constituents were apparently eroded by digestion, rendering discernibility increasingly difficult.

\section{Esophageal Fistula Method}

Microscopic analysis of esophageal extrusa was the single most accurate method of estimating diets under the constraints of the feeding trial. The discernibility of plant fragments in esophageal extrusa was greater than in rumen or fecal samples. Persistence of plant fragments in esophageal extrusa was greater than for any other sampling procedure since effects of cellular erosion due to digestion were probably least. Ingesta collected from the esophagus was an actual portion of the diet, and as such was not subject to the inherent sampling errors of utilization estimates (Laycock et al. 1972).

However, there is at least one reason for regarding the esophageal fistula method with some suspicion. Plant fragments found in esophageal extrusa represent the diet of the animal for only that length of time during which the fistula sample is being collected. Van Dyne and Heady (1965) reported differences in composition for plant parts, plant classes and some plant species when comparing morning to afternoon sampling. Rumen and fecal samples, however, are composed of plants which have been eaten at least throughout the entire day, so daily changes in selection are considered.

\section{Stomach Content Analysis}

The gross composition of the diet as determined by rumen a nalysis tended to be higher in graminoids and lower in forbs than that determined by utilization estimates (Fig. 3) and the esophageal fistula method (Fig. 1 and 3). However, rumen ingesta generally contained fewer graminoids and more forbs than fecal material (Fig. 1 and 3). The total forb component of rumen ingesta was significantly lower than that of esophageal ingesta for both trials. It was observed that while the discernibility of graminoids was about the same in rumen and esophageal ingesta, fragments of forb species were more difficult to recognize in rumen samples. The likelihood is that cellular erosion due to digestion was greater for forbs in the rumen, thus decreasing their discernibility.

Norris (1943) noted that succulent forages passed through the stomach more rapidly than coarse, fibrous portions of the diet. Assuming that such throughput time was more rapid for forbs than for grasses in the present study, rumen analysis would tend to overestimate the abundance of graminoids and underestimate the abundance of forbs.

\section{Fecal Analysis}

Microscopic examination of fecal material has become one of the most popular methods of determining the food habits of large herbivores. However, several limitations of the technique have become apparent in this study. Microscopic examination of fecal material showed a higher composition of total graminoids and lower composition of total forbs in the diet for both trials than

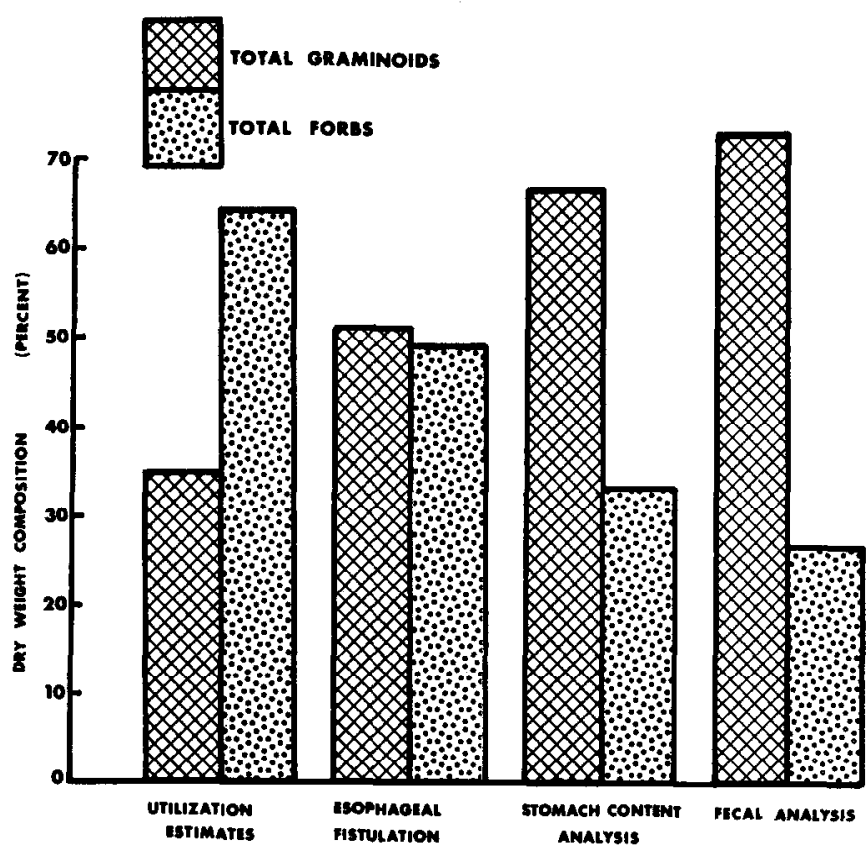

Fig. 3. Percent composition of total graminoids and forbs in diets as determined by 4 methods during the grazing trial.

other methods (Figures I and 3). Diets determined by fecal analysis were not as diverse as those determined by the other methods since several minor forbs were not found in feces during the grazing trial (Table 2).

These findings were consistent with those of other workers (Vavra et al. 1978, Korfhage 1974) and may be explained partially on the basis of differential digestibility. It is conceivable that certain species of forbs are entirely digested, leaving no residue in the feces (Slater and Jones 1971, Johnson and Pearson 1981). In other instances plant fragments were present but were so transparent that cellular structure was not easily discernible. This was particularly true with Oregon checkermallow. Identification of this species in fecal material was based more often on the unique characteristics of its stellate trichomes than on cellular structure. The accuracy of fecal analysis could probably be enhanced by the determination of digestibility coefficients of various plant species in different phenological stages, and for different animal species.

\section{Utilization Estimates}

Utilization estimates resulted in a diet lower in graminoids and higher in forbs than other methods (Fig. 3), and were most similar to results obtained by esophageal fistulation (Table 1). This trend was partially substantiated by Laycock et al. (1972), who found the composition of grasses in diets as determined by the ocularestimate-by-plot method was less than by the esophageal fistula method. Utilization estimates failed to show the presence of 4 species of grasses and 2 species of forbs (Table 2). Diminutive annuals such as soft chess posses weak rooting systems, which may have allowed the plant to be pulled out leaving no standing residue as evidence of utilization. Laycock et al. (1972) observed such "invisible utilization" of mountain knotweed (Polygonum montanum). Several forbs were either not identified by the other methods of dietary determination or found in only trace amounts (Table 2). It is likely that use of these species was too light to be detected by utilization estimates.

\section{Conclusions}

Food habits of large herbivores may be described using any of the methods tested. Absolute values of species contained in the diets varied depending upon the method used. Ocular estimates of forage utilization resulted in higher mean values for the composition of forbs and lower mean values for the composition of grami- 
noids than any other method. Rumen and fecal analysis overestimated less digestible portions of the diet while underestimating more digestible portions. Examination of esophageal extrusa was the most accurate method tested to determine food habits of large herbivores.

If dietary information is to be used to rank forage species important to an herbivore, all methods tested provided adequate data. Dietary information is frequently proposed as a data base for forage allocation. Given that factors including differences between years, physiographic features, and management practices are considered and accurately measured, and that responses of animals to these various factors are known, then such dietary determinations can be important in developing practical forage allocation models.

\section{Literature Cited}

Anthony, R.G., and N.S. Smith. 1974. Comparison of rumen and fecal analysis to describe deer diets. J. Wildl. Manage. 38:535-540.

Crocker, B.H. 1959. A method of estimating the botanical composition of the diet of sheep. N.Z.J. Agr. Res. 2:72-85.

Engels, E.A.N., and A. Malan. 1973. Sampling of pastures in nutritive evaluation studies. Agronanimalia 5:89-94.

Hall, F.C. 1973. Plant communities of the Blue Mountains in eastern Oregon and southeastern Washington. USDA Pacific Northwest Forest and Range Exp. Sta., Area Guide 3-1.

Harris, L.E., G.P. Lofgreen, C.J. Kercher, R.J. Raleigh, and V.R. Bohman. 1967. Techniques of research in range livestock nutrition. Utah Agr. Exp. Sta. Bull. 471.

Johnson, M.K., and H.A. Pearson. 1981. Esophageal, fecal and exclosure estimates of cattle diets on a longleaf pine-bluestem range. J. Range Manage. 34:232-234.

Korfhage, R.C. 1974. Summer food habits of elk in the Blue Mountains of northeastern Oregon based on fecal analysis. M.S. thesis. Washington State Univ., Pullman.

Laycock, W.A., H. Buchanan, and W.C. Krueger. 1972. Three methods of determining diet, utilization, and trampling damage on sheep range. $J$. Range Manage. 25:352-356.
Lesperance, A.L., V.R. Bohman, and D.W. Marble. 1960. Development of techniques for evaluating grazing forage. J. Dairy Sci. 43:682-689.

Lesperance, A.L., D.C. Clanton, A.B. Nelson, and C.B. Theurer. 1974 Factors affecting the apparent chemical composition of fistula samples. West. Region Coord. Comm. Pub. 8, Nevada Agr. Exp. Sta., Reno.

Martin, S.C. 1970. Relating vegetation measurements to forage consumption by animals. p. 93-100, In: Range and Wildl. Habitat Evaluation-A Res. Symp. USDA Forest Serv. Misc. Pub. 1147.

McCann, C.P., R.J. McLaren, K.L. Delay and J.K. Matsushima. 1973. Digestive tract cannulas for ruminants. Proc. West. Sect. Anim. Sci. 24:377-383.

Norris, J.J. 1943. Botanical analysis of stomach contents as a method of determining forage consumption of range sheep. Ecology 24:244-251.

Oosting, H.J. 1956. The study of plant communities-an introduction to plant ecology. W.H. Freeman and Co., San Francisco.

Pechanec, J.F., and G.D. Pickford. 1937a. A weight estimate method for the determination of range or pasture production. J. Amer. Soc. Agron. 29:894-904

Pehanec, J.F., and G.D. Pickford. 1937b. A comparison of some methods used in determining percentage utilization of range grasses. J. Agr. Res. 54:753-765.

Regal, V. 1960. The evaluation of the quality of pasture grasses by the microscope method. Proc. Eighth Int. Grassland Cong. 1960: 522-524.

Rice, R.W. 1970. Stomach content analysis: a comparison of the rumen vs esophageal techniques. p. 127-132. In: Range and Wildl. Habitat Evaluation-A Res. Symp. USDA Forest Serv. Misc. Pub. 1147.

Slater, J., and R.J. Jones. 1971. Estimation of the diets selected by grazing animals from microscopic analysis of the faeces-a warning. J. Aust. Inst. Agr. Sci. 37:238-240.

Smith, A.D., and L.J. Shandruk. 1979. Comparison of fecal, rumen and utilization methods for ascertaining pronghorn diets. J. Range Manage. 32:275-279.

Sparks, D.R., and J.C. Malechek. 1968. Estimating percentage dry weight in diets using a microscope technique. J. Range Manage. 21:264-265.

Steel, R.G.D., and J.H. Torrie. 1960. Principles and procedures of statistics. McGraw-Hill Book Co., New York.

Van Dyne, G.M., and H.F. Heady. 1965. Botanical composition of sheep and cattle diets on a mature annual range. Hilgardia 36:465-492.

Vavra, M., R.W. Rice, and R.M. Hansen. 1978. A comparison of esophageal fistula and fecal material to determine steer diets. J. Range Manage. 31:11-13.

SRM Policy on Section Affiliation: When a member moves from one Section to another, he automatically becomes a member of the Section where his new address is. If the member desires to remain a member of his previous Section, he must submit that request in writing to the Denver office.

A member may belong to more than one Section by paying the Section dues for each Section he wishes to be a member of. This must be sent to the Denver office in writing.

Please notify the Denver office concerning change of address as soon as the new address is known. 